\title{
ANALISIS PENGARUH INTELLECTUAL CAPITAL TERHADAP FIRM VALUE DENGAN ROA SEBAGAI VARIABEL MODERASI (STUDI EMPIRIS PADA SUB SEKTOR PERBANKAN YANG TERDAFTAR DI BEI TAHUN 2012-2016)
}

\author{
Zulkarnain \\ Program Studi Akuntansi, Institut Manajemen Wiyata Indonesia \\ zulkarnain@imwi.ac.id \\ Siti Annisa Failasufi \\ Program Studi Akuntansi, Institut Manajemen Wiyata Indonesia \\ afailasufi@gmail.com
}

\begin{abstract}
This research aims to analyze influence of intellectual capital on firm value with ROA as a moderating variable in banking companies in Indonesia. This research uses intellectual capital value added consisting of VACA, VAHU, and STVA as independent variable. This research also examines the relationship between intellectual capital and firm values which are moderated by financial ratios. The financial ratio used is return on assets which is used as a moderating variable. The samples consisted of 14 companies listed on the Indonesia Stock Exchange and published their financial statement in the 2012-2016 period. The data was used in this research was the secondary data and selected by using purposive techniques. The analysis implement that used was the linear regression analysis at a 5\% significance level. The results of this research provides evidence that intellectual capital value added which is the sum of VACA, VAHU, and STVA has a positive effect on the value of the firm by being moderated by ROA. Based on the results of this research, it was also provides evidence that intellectual capital affects the value of the firm by moderating ROA.
\end{abstract}

Keywords: intellectual capital, VACA, VAHU, STVA, firm value, price stock, and $R O A$

\section{PENDAHULUAN}

Perkembangan dunia usaha khususnya di Indonesia seiring berjalannya waktu semakin pesat dengan semakin berkembangnya IPTEK dan globalisasi. Hal tersebut berdampak pada timbulnya persaingan yang semakin ketat di antara perusahaan. Setiap perusahaan yang didirikan umumnya mempunyai dua tujuan, yaknitujuan jangka pendek dan tujuan jangka panjang. Adapun tujuan jangka pendek didirikannya perusahaan adalah laba yang maksimal, sedangkan tujuan jangka panjangnya yaitu mencapai nilai perusahaan yang maksimal (firm value). Nilai perusahaan yang maksimal dapat dicerminkan melalui harga pasar sahamnya, sehingga perusahaan saling bersaing untuk dapat mempertahankan nilai perusahaannya dengan berbagai cara demi menarik investor baru maupun memakmurkan para pemegang saham. Perusahaan dituntut agar terus berupaya untuk mempertahankan dan mengembangkan usahanya, salah satunya dengan memaksimalkan faktor-faktor penunjang dalam proses produksi yang menghasilkan 
output barang maupun jasa dalam kegiatan operasionalnya. Salah satu sumber pendukung kegiatan operasional perusahaan diantaranya adalah aset.

Hampir menginjak dua dasawarsa terakhir, tak sedikit perusahaan merubah strategi bisnisnya yang semula didasarkan pada tenaga kerja (labor-based business) menuju bisnis yang didasarkan pada pengetahuan (knowledge-based business) agar perusahaan dapat bersaing secara kompetitif dalam perekonomian global. Menurut Rahmawati, faktor utama yang dapat meningkatkan nilai perusahaan melalui knowledge based business adalah konsep modal intelektual. Penerapan sistem manajemen berdasarkan ilmu pengetahuan dalam knowledge based business menghadapi sebuah permasalahan yang berdampak pada pelaporan keuangan. Sistem pelaporan yang saat ini telah mapan secara berkelanjutan kehilangan relevansinya, hal demikian disebabkan karena laporan keuangan tidak mampu menyajikan informasi yang dibutuhkan para eksekutif untuk mengelola proses yang berbasis pengetahuan dan intangible resources. Menindaklanjuti hal tersebut, para pelaku bisnis tidak hanya merubah strategi bisnisnya pada pengetahuan saja, tetapi juga pada inovasi dan sistem informasi. Perubahan ekonomi yang berbasis ilmu pengetahuan menitik beratkan penerapan manajemen pengetahuan (knowledge management) untuk menciptakan kemakmuran perusahaan. Selain knowledge management, fokus ekonomi juga mengarah pada knowledge asset (aset pengetahuan) yang mengakibatkan adanya peningkatan yang cukup drastis terhadap perhatian praktik pengelolaan aset tidak berwujud. Hal tersebut memberikan dampak berupa adanya peningkatan yang besar pada knowledge workers dan aset tak berwujud. Knowledge workers dan aset tak berwujud dalam hal ini adalah sebuah tantangan tersendiri bagi para akuntan untuk dapat mengidentifikasi, mengukur, dan mengungkapkannya dalam laporan keuangan.

Terdapat pendekatan yang digunakan untuk menilai dan mengukur aset tidak berwujud dengan tujuan utama untuk memperoleh keuntungan dalam bersaing, salah satunya adalah melalui Intellectual Capital. Informasi intellectual capital merupakan salah satu informasi yang digunakan oleh para investor dalam pengambilan keputusan investasi dengan menjadikan informasi tersebut sebagai alat memprediksikan kinerja keuangan di masa yang akan datang.

Peran penting Intellectual Capital (IC) sebagai aset tak berwujud yang strategis bagi perusahaan telah terbukti melalui berbagai riset. Seperti salah satunya riset yang telah dibuktikan secara empiris oleh (Gunawan, Akhyar, \& Candrasari, 1996) dengan menggunakan model Pulic (VAICTM). Hasil riset tersebut menunjukkan bahwa perusahaan dengan IC yang tinggi dapat membuat investor memberikan nilai yang lebih tinggi pada perusahaan dengan melihat kinerja keuangan perusahaan. Hal tersebut juga selaras dengan penelitian yang dilakukan oleh Ozkanet al., (2016) di Turki yang menyebutkan bahwa IC memiliki dampak yang positif terhadap kinerja keuangan.

Di Indonesia sendiri, penelitian mengenai peran IC telah dilakukan oleh Hermawan (2012) dengan hasil penelitiannya yang senada dengan penelitian (Gunawan et al., 1996) di Turki , memperlihatkan bahwa IC terbukti memengaruhi kinerja bisnis, selain dapat meningkatkan nilai perusahaan, IC juga dapat meningkatkan efektifitas organisasi, competitive advantage, dan juga menciptakan 
kesejahteraan bagi perusahaan.

Namun hal tersebut berbeda dengan hasil penelitian mengenai IC yang dilakukan oleh Al-Musali dan Ismail (2014) di Arab Saudi yang mengungkapkan bahwa IC yang dihitung dengan menggunakan model VAIC ${ }^{\text {TM }}$ dengan indikator SCE menunjukkan hubungan yang tidak signifikan dengan kinerja keuangan. Penelitian ini konsisten dengan penelitian yang dilakukan oleh Mehralin et al., (2012) di Iran dan riset yang telah mendunia dari (Kusufiyah, Dahar, \& Rahmi, 2017) di Afrika Selatan yang menunjukkan bahwa tidak ada pengaruh positif antara IC dan kinerja keuangan, sebaliknya penelitian tersebut menyatakan bahwa aset berwujudlah yang merupakan sumber daya yang paling signifikan dalam kinerja keuangan dinegara-negara tersebut.

Seiring perkembangan dunia, beberapa penelitian terhadap Intellectual capital melakukan riset dengan menghubungkan antara Intellectual Capital dan harga saham. Penelitian terbaru mengenai pengaruh intellectual capital terhadap harga saham juga dilakukan oleh (Kusufiyah et al., 2017) yang menjadikan kinerja keuangan sebagai variabel moderating untuk mengetahui efek intellectual capital terhadap harga saham. dalam melakukan penelitiannya ini, (Kusufiyah et al., 2017) menggunakan ROA sebagai salah satu indikator kinerja keuangan dalam hubungannya antara intellectual capital dengan harga saham. Penelitian yang dilakukan oleh (Kusufiyah et al., 2017) ini menunjukkan bahwa ROA yang menjadi indikator kinerja keuangan yang digunakannya merupakan variabel pemoderasi murni yang dapat memperkuat hubungan intellectual capital terhadap harga saham. Ditambahkannya bahwa hal tersebut dikarenakan pengelolaan intellectual capital yang baik mempunyai dampak pada kinerja keuangan yang digambarkan melalui ROA sehingga dapat meningkatkan harga saham.

Berdasarkan yang telah dipaparkan di atas, dengan berbagai riset empiris terkait intellectual capital yang masih meninggalkan gap hasil penelitian, sehingga membuat peneliti tertarik untuk meneliti kembali apakah intellectual capital berpengaruh terhadap harga saham bank konvensional di Indonesia dengan kinerja keuangan sebagai variabel moderating.

\section{TINJAUAN PUSTAKA}

Merujuk pada paparan di atas, terdapat beberapa unsur yang perlu dijelaskan lebih lanjut dan disajikan secara jelas terkait variabel yang akan diuji kemudian.

\section{Teori Keagenan (Agency Theory)}

Menurut Supriyono teori keagenaan adalah konsep yang mendeskripsikan hubungan antara prinsipal (pemberi kontrak) dengan agen (penerima kontrak), prinsipal mengontrak agen untuk bekerja demi kepentingan atau tujuan prinsipal sehingga prinsipal memberikan wewenang pembuatan keputusan kepada agen untuk mencapai tujuan. Agen bertanggung jawab atas pencapaian tujuan tersebut dan agen menerima balas jasa dari prinsipal. Dalam hal organisasi perusahaan, prinsipal adalah para pemegang saham dan agen adalah manajemen puncak seperti dewan komisaris dan direksi.

\section{Teori Legitimasi (Legitimacy Theory)}

Dalam perspektif teori legitimasi, suatu perusahaan akan secara sukarela aktivitasnya karena manajemen menganggap bahwa ini adalah yang diharapkan komunitas. Hal tersebut berdasar pada pengertian teori legitimasi yang 
menyatakan bahwa organisasi secara berkelanjutan mencari cara untuk menjamin operasi mereka berada dalam batas dan norma yang berlaku di masyarakat. Teori legitimasi sangat erat hubungannya dengan pelaporan intellectual capital sebagai ukuran dari pelaporan tersebut.

Menurut pandangan teori legitimasi ini, perusahaan akan terdorong untuk menunjukkan kapasitan intellectual capitalnya dalam laporan keuangan untuk memperoleh legitimasi dari publik atas kekayaan intelektual yang dimilikinya. Pengakuan legitimasi publik ini menjadi penting bagi perusahaan untuk mempertahankan eksistensinya dalam lingkungan sosial perusahaan yang akan berdampak baik terhadap nilai perusahaan.

\section{Nilai Perusahaan (Firm Value)}

Nilai perusahaan (firm value) merupakan sebuah nilai yang dapat digunakan untuk mengukur seberapa besar "Tingkat Kepentingan" sebuah perusahaan dilihat dari sudut pandang beberapa pihak seperti para investor yang mengaitkan nilai sebuah perusahaan dari harga sahamnya. Pada dasarnya nilai perusahaan dapat diukur melalui beberapa aspek, diantaranya: pendekatan laba, pendekatan arus kas, pendekatan dividen, pendekatan asset, pendekatan economic value added, dan pendekatan harga saham.

Memaksimalkan nilai perusahaan sama dengan memaksimalkan harga saham dan itu juga yang diinginkan pemilik perusahaan karena nilai perusahaan yang tinggi mengindikasikan kemakmuran pemegang saham yang tinggi. Selaras dengan yang dikatakan oleh Suroto dalam penelitiannya bahwa semakin tinggi harga saham maka semakin tinggi nilai perusahaan, semakin tinggi nilai perusahaan maka akan semakin tinggi juga kemakmuran para pemilik saham. Mengacu pada aspek pengukuran nilai perusahaan, penulis memilih menggunakan pendekatan harga saham sebagai alat untuk memproyeksikan nilai perusahaan.

\section{Harga Saham}

Harga saham diartikan sebagai harga suatu saham pada pasar yang sedang berlangsung di bursa efek. Selanjutnya menurut Sartono, harga saham adalah harga yang terbentuk dari kesepakatan penjual dan pembeli saham atau harga yang terbentuk dari kekuatan permintaan dan penawaran saham yang terjadi di pasar bursa pada saat tertentu.

Harga saham sering megalami fluktuasi naik-turun, bahkan dari harga tertinggi ke terendah ataupun sebaliknya. Salah satu factor yang dapat mempengaruhi fluktuasi harga saham adalah asset. Asetyang mengalami peningkatan diikuti oleh peningkatan hasil operasi akan semakin menambah kepercayaan pihak luar terhadap perusahaan. Hal tersebut didasarkan pada keyakinan kreditor atas dana yang ditanamkan ke perusahaan dijamin besarnya oleh aset yang dimiliki perusahaan, sehingga semakin besar peningkatan aset akan meningkatkan harga saham.

\section{Aset}

Aset merupakan sumber daya yang dikendalikan perusahaan sebagai akibat adanya transaksi masa lalu dan masih memiliki manfaat dimasa yang akan datang.

\section{Intellectual Capital}

Secara umum, intellectual capital adalah ilmu pengetahuan atau daya pikir, yang dimliki oleh perusahaan, tidak memiliki bentuk fisik (tidak berwujud), dan dengan adanya intellectual capital tersebut, perusahaan akan 
mendapatkan tambahan keuntungan atau kemapanan proses usaha serta memberikan perusahaan suatu nilai lebih dibanding dengan kompetitor atau perusahaan lain. Intellectual capital dibedakan menjadi tiga komponen utama, berdasarkan yang dikemukakan oleh International Federation of Accountants (1998), yaitu Human Capital, Capital Employee, dan Structural Capital.

Meskipun intellectual capital adalah suatu hal yang sulit diukur, namun ada salah satu peneliti yang telah berhasil mengungkapkan pengukuran intellectual capital, peneliti tersebtu adalah Pulic pada tahun 1998, yakni metode VAIC ${ }^{\text {TM }}$. Value Added Intellectual Coefficient (VAIC ${ }^{\mathrm{TM}}$ ) merupakan salah satu pengukuran dengan metode tidak langsung untuk mengukur seberapa besar dan bagaimana efisiensi intellectual capital dan modal karyawan menciptakan nilai yang berdasar pada hubungan tiga komponen utama, yaitu capital employee, human capital, dan structural capital. Pengukuran VAIC tersebut diantaranya adalah:

1. Value Added Human Capital (VAHU)
Value added human capital mengindikasikan kemampuan tenaga kerja untuk menghasilkan nilai bagi perusahaan dari dana yang dikeluarkan untuk tenaga kerja tersebut.

2. Value Added Capital Employee (VACA)

Value added of capital employee (VACA) menggambarkan seberapa banyak value added yang dihasilkan dari modal fisik yang digunakan.

3. Structural Capital Value Added (STVA)

Structural capital value added (STVA) menunjukkan kontribusi structural capital (SC) dalam penciptaan nilai.

\section{ROA}

Return of Asset (ROA) merupakan salah satu rasio yang menunjukkan rasio profitabilitas. Menurut Chen, ROA adalah salah satu rasio kinerja keuangan yang merefleksikan keuntungan bisnis dan efisiensi perusahaan dalam pemanfaatan total asset.

\section{MODEL ANALISIS dan HIPOTESIS}

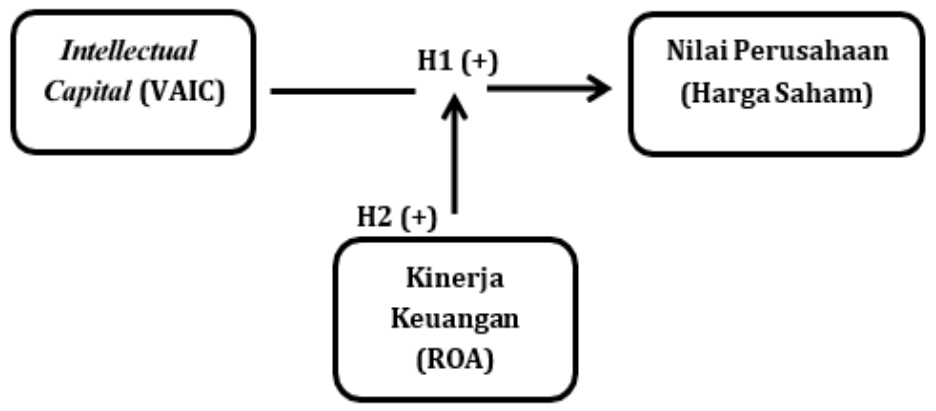

Gambar 1

Metode Analisis

Berdasarkan model analisis di atas, terdapat beberapa hipotesis penelitian 
sebagai berikut:

$\mathrm{H1}$ Intellectual Capital memiliki hubungan positif terhadap nilai perusahaan.

$\mathrm{H} 2$ : Kinerja keuangan yang diwakili oleh rasio profitabilitas melalui ROA mampu memberikan kontribusi positif dalam memoderasi hubungan antara Intellectual Capital dengan nilai perusahaan.

\section{METODE PENELITIAN}

Pada penelitian ini akan membahas mengenai hubungan antara intellectual capital dan nilai perusahaan yang diproyeksikan oleh harga saham dengan dimoderasi oleh rasio profitabilitas yaitu ROA. Penelitian ini menggunakan pendekatan penelitian kuantitatif.

\section{Populasi dan Sampel}

Priyono (2014) berpendapat populasi adalah keseluruhan gejala/satuan yang ingin diteliti, sedangkan sampel merupakan bagian dari populasi yang ingin diteliti. Populasi dalam penelitian ini adalah semua perusahaan subsektor perbankan yang terdaftar di Bursa Efek Indonesia (BEI) antara periode 20122016.

Sementara sampel menurut Sugiyono (2016) merupakan sebagian kecil dari populasi yang dapat dijadikan sebagai wakil dari populasi dengan prosedur dan kriteria yang telah peneliti pilih dalam penelitiannya.

Terdapat beberapa teknik pengambilan sampel, dalam penelitian ini peneliti mengggunakan non-probability sampling dengan purposive sampling sebagai teknik pengambilan sampelnya. Menurut (Siyoto \& Sodik, 2015) non- probability sampling adalah teknik yang tidak memberikan peluang/kesempatan sama bagi setiap unsur atau anggota populasi untuk dipilih menjadi sampel, dan purposive sampling merupakan suatu teknik penentuan sampel dengan pertimbangan tertentu atau seleksi khusus.

Adapun kriteria khusus yang menjadi acuan penulis dalam pengambilan sampel adalah sebagai berikut:

a. Perusahaan sebagai sampel yang telah menerbitkan dan mempublikasikan laporan keungan yang telah diaudit selama 5 (lima) tahun berturut-turut serta tidak mengalami kerugian pada tahun pelaporan tersebut;

b. Data yang tersaji dalam laporan keuangan tersebut tersedia secara lengkap mencakup variabel-variabel yang digunakan dalam penelitian;

c. Periode laporan keuangan perusahaan berakhir pada setiap 31 Desember.

\section{Operasionalisasi Variabel}

a. Variabel Dependen pada penelitian ini adalah nilai perusahaan, yang akan diproyeksikan dengan harga saham. . Harga saham perusahaan yang digunakan diambil dari nilai closing price saham yang diterbitkan perusahaan di BEI pada akhir periode (31 Desember).

b. Variabel Independen atau yang sering disebut juga sebagai variabel bebas dalam penelitian ini adalah Intellectual Capital, yang merupakan merupakan aset tidak berwujud, termasuk informasi dan pengetahuan yang dimiliki badan usaha yang harus dikelola dengan baik untuk memberikan keunggulan kompetitif bagi perusahaan, dari elemen human capital, structural capital dan customer capital yang dapat memberikan nilai lebih atau 
$\begin{array}{lcrr}\text { keuntungan } & \text { bagi perusahaan } & \text { serta } \\ \text { pengetahuan } & \text { yang dikelola } & \text { oleh } \\ \text { perusahaan } & \text { dengan baik } & \text { akan }\end{array}$ memberikan keunggulan kompetitif.

Intellectual Capital dalam penelitian ini diukur berdasarkan value added yang terbentuk dari tiga komponen VAIC ${ }^{\mathrm{TM}}$, diantaranta VACA (employee capital), VAHU (human capital), dan STVA (structural capital).

c. Variabel Moderasi

Moderating variable juga dapat diartikan sebagai variabel yang mempunyai pengaruh terhadap sifat atau arah hubungan antar variabel. Moderating variable dalam penelitian adalah salah satu komponen dari kinerja keuangan, yaitu ROA (return on asset).

\section{Metode Analisis}

Metode analisis yang digunakan pada penelitian ini adalah analisis regresi dan MRA. Metode analisis juga diperkuat dengan adanya peranan statistik deskriptif dan pengujian asumsi klasik, serta analisis regresi sederhana.

\section{Statistik Deskriptif}

Statistik deskriptif akan menghasilkan sebuah gambaran atau deskripsi data yang akan menyajikan beberapa informasi seperti jumlah data, nilai rata- rata, nilai minimum, nilai maksimum, dan standar deviasi sehingga melalui informasi tersebut akan membuat data mudah dipahami.

\section{Pengujian Asumsi Klasik}

\section{a. Uji Normalitas}

Uji normalitas pada penelitian ini dengan menggunakan uji Kolmogorov Smirnov satu arah. Untuk pengambilan keputusan terkait data tersebut berdistirbusi normal atau tidak dapat ditentukan dengan melihat hasil signifikansinya, jika signifikan >0,05 maka variabel dapat dikatakan berdistribusi normal, sedangkan jika signifikan $<0,05$ maka variabel dikatakan tidak berdistribusi normal.

\section{b. Uji Multikolinearitas}

Uji multikolinearitas ini bertujuan untuk menguji apakah dalam persamaan regresi ditemukan adanya korelasi antar variabel independen. Metode untuk menguji adanya multikolinearitas ini dapat dilihat dari Tolerance Factor (VIF), jika VIF > 10 atau jika tolerance value < 0,1 maka terjadi multikolinearitas, dan apabila VIF $<10$ atau jika tolerance value > 0,1 maka tidak terjadi multikolinearitas.

\section{c. Uji Autokolerasi}

Uji autokorelasi digunakan untuk mengetahui ada atau tidaknya penyimpangan asumsi klasik autokorelasi, yaitu korelasi yang terjadi antara residual pada suatu pengamatan dengan pengamatan lain pada model regresi. Untuk mengetahui apakah terjadi autokorelasi dalam suatu model regresi, dapat digunakan uji Run Test dengan melihat tingkat signifikansinya, apablia tingkat signifikasi > 0,05 maka artinya tidak terjadi autokorelasi.

\section{d. Uji Heteroskesdastisitas}

Uji heteroskedastisitas bertujuan untuk menguji apakah dalam model regresi terjadi ketidaksamaan varians dari residual satu pengamatan ke pengamatan yang lain. Jika varians tetap maka disebut homoskedastisitas dan jika berbeda maka terjadi problem heteroskedastisitas. 
Teknik yang digunakan dalam penelitian ini adalah dengan menggunakan uji gletser.

\section{Regresi Linier Sederhana}

Regresi linier sederhana pada penelitian ini digunakan untuk mengetahui ada atau tidaknya pengaruh dari variabel independen yaitu intellectual capital terhadap variabel dependen, dalam hal ini yaitu nilai perusahaan yang diproyeksikan oleh harga saham.

\section{MRA (Moderating Regression Analysis)}

MRA atau analisis regresi moderasi merupakan analisis regresi yang melibatkan variabel moderasi dalam membangun model hubungannya. Variabel moderasi berperan menyertai variabel independen dan berfungsi mempengaruhi hubungan variabel independen dengan variabel dependen.

\section{HASIL PENELITIAN dan PEMBAHASAN \\ Hasil Analisa Deskriptif}

Hasil statistik deskriptif menunjukkan bahwa dari total $\mathrm{n} 75$ data, nilai terendah dari Intellectual Capital adalah sebesar 2,23 dan nilai tertinggi adalah 8,90. Selain itu dapat diketahui juga bahwa nilai rata- rata VAIC sebesar 3,7439, hal tersebut mengindikasikan bahwa rata-rata keberhasilan perusahaan mendapatkan nilai tambah dari hasil penjumlahan setiap komponen Intellectual Capital yang terdiri dari VACA, VAHU, dan STVA adalah sebesar 3,74, dan mempunyai nilai standar deviasi sebesar 1,015. Hasil tersebut menunjukkan hasil yang baik, karena standar deviasi yang mencerminkan penyimpangan dari data tersebut mempunyai nilai lebih kecil daripada nilai rata- ratanya.

Kinerja keuangan perusahaan dalam hal ini diukur dengan ROA (return on asset) mempunyai nilai rata-rata sebesar 2,4777. Dalam hal ini ROA memperlihatkan bahwa perusahaan yang menjadi sampel mampu memperoleh rata-rata laba dan total aset sebesar 2,48\% dengan nilai terkecil 1,00\% pada Bank Capital Indonesia Tbk. di tahun 2016 dan nilai tertinggi sebesar 5,15\% pada Bank Rakyat Indonesia Tbk. di tahun 2012. Nilai standar deviasi ROA menunjukkan angka 1,04209 yang mana nilai tersebut juga merupakan hasil yang baik karena lebih kecil daripada nilai rata-ratanya.

Selanjutnya dari segi nilai perusahaan yang diproyeksikan oleh closing price mempunyai nilai rata-rata sebesar $\mathrm{Rp}$. 3750,6 dengan nilai minimum Rp. 88 yaitu Bank Capital Indonesia Tbk. pada tahun 2013, sementara nilai maksimum adalah Rp.15.500 yaitu pada Bank Central Asia Tbk pada tahun 2016. Dalam hal nilai strandar deviasi melalui closing price adalah sebesar 3830,26. Hal tersebut menunjukkan nilai penyimpangan harga saham dari data sampel yaitu sebesar 3830,26.

\section{Pengujian Asumsi Klasik}

Pengujian asumsi klasik yang digunakan dalam penelitian ini terdiri dari 4 pengujian, yaitu Uji Normalitas, Uji Multikolinearitas, Uji Autokorelasi, dan Uji Heteroskesdastisitas. Hasil pengujian asumsi klasik akan disajikan dan disajikan berikut ini.

\section{a. Uji Normalitas}

Pada penelitian ini acuan untuk pengambilan keputusan terkait data tersebut berdistirbusi normal atau tidak dapat ditentukan dengan melihat hasil 
signifikansinya, jika signifikan > 0,05 maka variabel dapat dikatakan berdistribusi normal, sedangkan jika signifikan $<0,05$ maka variabel dikatakan tidak berdistribusi normal.

Adapun hasil dari pengujian ini adalah nilai signifikan uji normalitas dari nilai residual data pengamatan tersebut menunjukkan nilai sebesar 0,176 yang berarti bahwa nilai tersebut adalah > 0,05 sehingga dapat diputuskan bahwa data pengamatan dalam penelitian ini berdistribusi normal.

\section{b. Uji Multikolinearitas}

Pada penelitian ini acuan untuk pengambilan keputusan terkait data tersebut. terjadi multikolinearitas atau tidak, dapat dilihat dari Tolerance Factor (VIF), jika VIF > 10 atau jika tolerance value $<0,1$ maka terjadi multikolinearitas, dan apabila VIF $<10$ atau jika tolerance value $>0,1$ maka tidak terjadi multikolinearitas.

Dari hasil pengujian tersebut didapati nilai VIF tersebut menunjukkan nilai sebesar 1,274 yang berarti bahwa nilai tersebut adalah $<10$ atau nilai tolerance sebesar 0,785 yang berarti bahwa nilai tersebut adalah > 0,1 sehingga dapat diputuskan bahwa data model variabel penelitian ini tidak terjadi multikolinearitas.

\section{c. Uji Autokorelasi}

Pada penelitian ini acuan untuk pengambilan keputusan terkait data tersebut. terjadi autokorelasi atau tidak, dapat dilihat dari nilai hasil uji Runs Test, kriteria suatu penelitian terjadi atau tidak terjadi autokorelasi adalah dengan melihat tingkat signifikansinya, apablia tingkat signifikasi > 0,05 maka artinya tidak terjadi autokorelasi.

Berdasarkan hasil pengujian autokorelasi nilai signifikan menunjukkan nilai sebesar 0,081 . Sesuai dengan kriteria Uji Runs Test bahwa suatu penelitian tidak terdapat autokorelasi jika nilai signifikan > 0,05 maka dapat diputuskan bahwa data model variabel penelitian ini tidak terdapat autokorelasi dikarenakan 0,081>0,05.

\section{d. Uji Heteroskesdastisitas}

Model regresi yang baik yaitu homoskesdatisitas atau tidak terjadi heteroskedastisitas. Adapun uji heteroskesdastisitas pada penelitian ini adalah dengan menggunakan Uji Glejser. Pengujian ada atau tidaknya gejala heteroskesdastisitas dengan menggunakan uji Glejser ini bertujuan untuk mengetahui apakah dalam model regresi terjadi ketidaksamaan varians dari residual satu pengamatan ke pengamatan lainnya. Dasar pengambilan keputusan untuk menentukan ada atau tidaknya gejala heteroskesdastisitas dalam suatu regresi menggunakan uji Geljser ini ialah dengan hasil nilai signifikansi. Apabila nilai signifikansi lebih besar dari 0,05 (sig > $0,05)$ maka dapat diputuskan bahwa tidak terjadi gejala heteroskesdastisitas. Sebaliknya, apablia nilai signifikansi kurang dari $0,05(\operatorname{sig}<0,05)$ maka terjadi adanya gejala heteroskesdastisitas.

Adapun hasil pengujian heteroskesdastisitas menggunakan Uji Glejser adalah sebagai berikut: 


\section{Uji Glejser \\ Coefficients}

\begin{tabular}{llrrrrr}
\hline Model & \multicolumn{7}{c}{$\begin{array}{l}\text { Unstandardized } \\
\text { Coefficients }\end{array}$} & \multicolumn{2}{c}{$\begin{array}{l}\text { Standardized } \\
\text { Coefficients }\end{array}$} & t & \multirow{2}{*}{ Sig. } \\
\cline { 3 - 5 } & \multicolumn{1}{c}{ B } & Std. Error & \multicolumn{1}{c}{ Beta } & & \\
\hline 1 & (Constant) & 3651,136 & 3989,156 & &, 915 &, 363 \\
\hline & $-1561,422$ & 1059,628 &,- 414 & $-1,474$ &, 145 \\
\hline & VAIC & $-869,168$ & 1602,338 &,- 236 &,- 542 &, 589 \\
\hline
\end{tabular}

a. Dependent Variable: abs_res

Sumber: Hasil Pengolahan SPSS, 2018.

Berdasarkan hasil uji Glejser yang telah disajikan di atas, dapat dilihat bahwa nilai signifikansi untuk variabel $\mathrm{X} 1$ (VAIC) menunjukkan nilai sebesar 0,145 , dan nilai signifikansi variabel $\mathrm{X} 2$ (ROA) menunjukkan nilai 0,589 . Merujuk pada dasar pengambilan keputusan uji Glejser sebelumnya, maka dengan hasil pengujian tersebut dapat diputuskan bahwa dalam model regresi pengamatan ini tidak terjadi gejala heteroskesdastisitas. Hal tersebut dikarenakan masing-masing variabel memiliki nilai signifikansi lebih besar dari 0,05 (sig >0,05).

\section{Uji Hipotesis}

Dalam penelitian ini pengujian hipotesis yang digunakan adalah pengujian koefisien determinasi, moderating regression analysis, dan uji signifikan parameter individual (uji t).

\section{Uji Regresi Linier Sederhana}

Model persamaan regresi linier sederhana padapenelitian ini adalah:

Tabel 2

Regresi Linier Sederhana

Coefficients $^{\mathbf{a}}$

\begin{tabular}{|c|c|c|c|c|c|c|}
\hline \multirow[t]{2}{*}{ Model } & \multicolumn{2}{|c|}{$\begin{array}{l}\text { Unstandardized } \\
\text { Coefficients }\end{array}$} & \multirow{2}{*}{\multicolumn{2}{|c|}{$\begin{array}{c}\begin{array}{c}\text { Standardized } \\
\text { Coefficients }\end{array} \\
\text { Beta }\end{array}$}} & \multirow[t]{2}{*}{$\mathbf{t}$} & \multirow[t]{2}{*}{ Sig. } \\
\hline & B & Std. Error & & & & \\
\hline (Constant) & $-2705,754$ & 1522,824 & & & $-1,777$ & ,080 \\
\hline 1 & & & & & & \\
\hline VAIC & 1724,515 & 392,754 & & , 457 & 4,391 &, 000 \\
\hline
\end{tabular}

a. Dependent Variable: ClosingPrice

Sumber: Hasil Pengolahan SPSS, 2018.

Dari tabel hasil pengujian tersebut dapat diketahui nilai konstanta adalah 2705,754 dan nilai adalah 1724,515 sehingga diperoleh model regresi linier sederhana sebagai berikut:

$$
\text { ClosingPrice }=-2705,754+1724,515\left(\text { VAIC }^{\mathrm{TM}}\right)
$$

Merujuk pada tabel di atas, dilihat bahwa nilai Beta adalah 0,457 yang mana nilai tersebut merupakan angka positif, hal tersebut mengindikasikan bahwa variabel pada model regresi dalam penelitian ini mempunyai arah hubungan yang positif. 


\section{Uji Koefisien Determinasi}

Berdasarkan hasil perhitungan uji koefisien determinasi diperoleh nilai $R$ Square adalah sebesar 0,209. Hal tersebut dapat diartikan bahwa nilai perusahaan yang diproksikan dengan closing price dapat dijelaskan oleh variabel independen sebesar 20,9\% sedangkan sisanya sebesar $79,1 \%$ dipengaruhi variabel lain yang tidak diteliti.

\section{MRA (Moderating Resression Analysis)}

Moderating regression analysis ini digunakan dalam pengujian hipotesis yang bertujuan untuk mengetahui pengaruh intellectual capital terhadap harga saham dengan dimoderasi oleh ROA (return on asset).

Berdasarkan hasil perhitungan MRA, didapat nilai $R$ Square adalah sebesar 0,581 atau sebesar $58,1 \%$. Sehingga dapat diketahui bahwa ROA dalam hal ini sebagai variabel moderasi berhasil meningkatkan pengaruh variabel independent sebesar 0,372 atau sebesar $37,2 \%$ terhadap variable dependen.

\section{Uji t}

Hasil uji t atau uji signifikan parameter individual pada penelitian ini adalah:

1. Uji Signifikan Parameter Individual (H1) Hipotesis pertama: Intellectual Capital memiliki hubungan positif terhadap nilai perusahaan. Berdasarkan tabel regresi di atas dapat dilihat nilai signifikansi adalah 0,000 yang berarti $0,000<0,05$, serta thitung dari variabel independen (intellectual capital) adalah sebesar 4,391 yang berarti $\mathrm{t}$ hitung > $\mathrm{t}$ tabel $(4,391>$ 1,99300) maka H1 diterima, sehingga dapat dikatakan bahwa intellectual capital berpengaruh terhadap harga saham.

2. Uji Signifikan Parameter Individual (H2) Hipotesis kedua: Kinerja keuangan yang diwakili oleh rasio profitabilitas melalui ROA mampu memberikan kontribusi positif dalam memoderasi hubungan antara Intellectual Capital dengan nilai perusahaan.

Berdasarkan tabel regresi di atas dapat dilihat nilai signifikansi adalah 0,039 yang berarti $0,039<0,05$, serta thitung dari variabel independen (intellectual capital) adalah sebesar 2,107 yang berartit hitung > t tabel $(2,107>1,99300)$ maka $\mathrm{H} 2$ diterima, sehingga dapat dikatakan bahwa intellectual capital berpengaruh terhadap harga saham dengan dimoderasi oleh ROA (return on asset).

\section{Pembahasan Penelitian}

Berdasarkan hasil pengujian hipotesis menggunakan model regesi di atas, maka dapat diketahui bahwa hasil perhitungan $\mathrm{R}^{2}$ menunjukkan intellectual capital mempunyai pengaruh terhadap harga saham sebesar 20,9\% dalam membantu mencerminkan nilai tambah dari intellectual capital terhadap harga saham perusahaan perbankan yang terdaftar di BEI tahun 2012-2016.

Hipotesis pertama dalam penelitian ini adalah intellectual capital berpengaruh terhadap harga saham perusahaan. Berdasarkan hasil uji t yang ditunjukkan pada tabel 4.10 memperlihatkan hasil $t$ hitung dari model regresi pada variabel X (intellectual capital) adalah 4,391 yang berarti lebih besar dari pada t tabel dengan nilai sebesar 1,99300 dan jika dilihat dari nilai sig $=0,000<0,05$ maka 
dapat disimpulkan bahwa H1 diterima, sehingga dalam hal ini berarti intellectual capital berpengaruh terhadap harga saham. Penelitian ini menunjukkan bahwa semakin besar nilai tambah dari intellectual capital maka akan semakin berpengaruh terhadap harga saham. Ketika intellectual capital dikelola dengan maksimal dapat menghantarkan perusahaan pada perfoma yang baik. Dan dengan adanya perfoma baik yang ditunjukkan oleh perusahaan maka akan menarik banyak investor untuk berinvestasi pada perusahaan tersebut sehingga dapat menaikkan harga saham perusahaan tersebut. Intellectual capital yang merupakan penjumlahan antara komponen $\mathrm{HC}, \mathrm{CE}$, dan SC berdasarkan hasil penelitian ini menunjukkan bahwa seluruh komponen intellectual capital telah berperan dalam mendukung peningkatan harga saham perusahaan. Hal ini didukung oleh teori keagenan (agency theory) dan teori legitimasi (legitimacy theory), dimana ketika manajemen mampu mengelola organisasi secara maksimal terlebih dalam upaya penciptaan nilai bagi perusahaan. Hasil penelitian ini melalui metode VAICTM telah berhasil menyajikan informasi tentang value creation sesuai dengan tujuan dibuatnya metode ini oleh Pulic. Penciptaan nilai (value creation) dalam konteksini adalah dengan memanfaatkan seluruh potensi yang dimiliki perusahaan, baik dari segi karyawan (human capital), aset fisik, dan structural capital. Pengelolaan yang baik atas seluruh potensi ini akan menciptakan value added bagi perusahaan yang kemudian dapat mendorong kinerja keuangan sehinggapada akhirnya dapat menaikkan harga saham. Penelitian ini berhasil membuktikan bahwa perusahaan sektor perbankan sebagai sampel telah mampu mengelola setiap komponen pembentuk intellectual capitalnya dengan baik sehingga dapat berdampak terhadap saham perusahaan. Rasionalisasi terhadap hal tersebut adalah secara umum dalam lima tahun pengamatan, value added perusahaan perbankan di Indonesia sebagai sampel dalam penelitian ini telah berhasil memanfaatkan dan memaksimalkan keahlian, pengetahuan, jaringan serta olah pikir karyawannya guna menciptakan nilai bagi perusahaan dan berdampak mempunyai potensi dalam hal menaikkan harga saham perusahaan perbankan yang terdaftardiBEI tahun2012-2016.

Hipotesis kedua dalam penelitian ini adalah intellectual capital berpengaruh terhadap harga saham perusahaan dengan ROA sebagai variabel moderasi. Berdasarkan hasil uji t yang ditunjukkan pada tabel 4.11 memperlihatkan hasil $\mathrm{t}$ hitung dari model regresi linear berganda adalah 2,107 yang berartilebih besar daripada ttabeldengannilai sebesar 1,99300 danjikadilihat dari nilai sig= $0,039<0,05$ maka dapat disimpulkan bahwa $\mathrm{H} 2$ diterima, sehingga dalam hal ini berarti ROA berpengaruh terhadap hubungan intellectual capital dan harga saham. Signifikansi hasil penelitian menunjukkan bahwa berarti ROA mampu memoderasi hubungan intellectual capital dan harga saham. Hal tersebut dikarenakan oleh pengelolaan intellectual capital yang baik berdampak pada kinerja keuangan yang digambarkan salah satunya oleh profitabilitas yaitu ROA sehingga dapat meningkatkan harga saham. Penelitian ini berhasil membuktikan bahwa perusahaan sektor perbankan sebagai sampel yang telah mampu mengelola setiap komponen pembentuk intellectual capitalnya dengan 
baik sehingga dapat berpengaruh terhadap kinerja perusahaan yang pada akhirnya akan meningkatkan nilai perusahaan dan menaikkan harga saham perusahaan tersebut. Rasionalisasi terhadap hal tersebut adalah secara umum dalam lima tahun pengamatan, value added dari intellectual capital perusahaan perbankan di Indonesia sebagai sampel dalam penelitian ini mempunyai hubungan terhadap nilai perusahaan dengan dimoderasi oleh profitabilitas yang merupakan salah satu pengukuran kinerja keuangan. Hal tersebut mengindikasikan keberhasilan kinerja keuangan yang diproyeksikan oleh ROA sebagai variabel moderasi dikarenakan adanya penilaian investor terhadap seluruh komponen intellectual capital sehingga dapat meningkatkan kinerja keuangan dan kemudian berdampak pada harga saham.

\section{KESIMPULAN}

Penelitian ini dilakukan dengan tujuan untuk menyajikan bukti empiris mengenai hubungan antara intellectual capital terhadap nilai perusahaan yang dalam hal ini tercermin melalui harga saham dengan kinerja keuangan yang diproyeksikan oleh ROA sebagai variabel moderasi pada perushaan perbankan yang terdaftar di Bursa Efek Indonesia tahun 2012 sampai dengan tahun 2016. Kesimpulan dari hasil pengujian dan analisis data adalah sebagai berikut:

1. Penelitian ini menemukan bahwa intellectual capital dengan menggunakan metode VAIC ${ }^{\text {TM }}$ mempunyai pengaruh positif terhadap nilai perusahaan.

2. Penelitian ini juga menemukan bahwa intellectual capital berpengaruh terhadap nilai perusahaan melalui kinerja keuangan yang diukur dengan menggunakan variabel ROA. ROA merupakan variabel moderasi yang dapat memoderasi hubungan intellectual capital terhadap nilai perusahaan. Hal tersebut disebabkan oleh pengelolaan intellectual capital yang baik yang dilakukan oleh perusahaan sehingga berdampak pada kinerja keuangan yang dalam hal ini diproyeksikan oleh ROA dan dapat meningkatkan harga saham sebagai salah satu cermin dari nilai perusahaan.

\section{Saran}

Berdasarkan penjelasan dari pembahasan dalam penelitian ini, peneliti ingin menyampaikan beberapa saran yang mana saran tersebut diharapkan dapat diterapkan oleh peneliti selanjutnya untuk menambah literatur dan pengembangan ilmu pengetahuan terhadap studi mengenai intellectual capital di masa mendatang, dan juga oleh perusahaan baik perusahaan sampel maupun perusahaan lainnya. Adapun saran tersebut adalah sebagai berikut:

1. Dalam upaya menambah literatur dan pengembangan ilmu pengetahuan terhadap studi mengenai intellectual capital di masa mendatang, saran yang dapat peneliti sampaikan bagi peneliti selanjutnya, yaitu:

a. Dalam penelitian ini, perhitungan intellectual capital terbatas hanya dengan menggunakan metode VAICTM dari Pulic, sehingga memungkinkan masih terdapat keterbatasan pengukuran intellectual capital sebenarnya pada peusahaan. Maka dari itu, diharapkan pada penelitian selanjutnya dapat menggunakan metode pengukuran lain untuk 
mengetahui nilai intellectual capital suatu perusahaan.

b. Dikarenakan dalam penelitian ini hanya menggunakan data perusahaan perbankan sebagai populasi, sehingga masih banyak subsektor perusahaan yang terdaftar di Bursa EfekIndonesia yang belum diteliti mengenai nilai tambah dari intellectual capital. Maka dari itu, diharapkan penelitian selanjutnya lebih baik menggunakan data selain perusahaan perbankan.

c. Penelitian ini hanya menguji pada perusahaan perbankan konvensional saja, sedangkan saat ini sektor perbankan syariah juga menjadi suatu ketertarikan tersendiri dan masih belum banyak penelitian tentang intellectual capital pada perbankan syariah, sehingga diharapkan penelitian selanjutnya dapat menguji intellectual capital pada perusahaan perbankan syariah dengan menggunakan metode lain selain VAICTM .

d. Pada penelitian ini variabel kinerja keuangan yang digunakan hanya profitabilitas saja dan hanya ROA yang dijadikan data pengujian, sedangkan masih banyak pengukuran kinerja keuangan yang lain yang tidak diteliti dalam penelitian ini. Sehingga diharapkan penelitian selanjutnya hendaknya melakukan penelitian menggunakan variabel kinerja keuangan yang lain atau melakukan penambahan variabel lain seperti likuiditas, umur perusahaan, dll.

e. Pengukuran nilai perusahaan dalam penelitian ini adalah dengan diproyeksikan oleh harga saham, namun masih banyak faktor lain yang dapat dilakukan untuk mengukur nilai perusahaan, sehingga diharapkan penelitian selanjutnya hendaknya menggunakan pengukuran nilai perusahaan yang lain, seperti pengukuran dengan metode Tobin's, PBV, dll.

2. Saran praktis bagi perusahaan adalah perusahaan dapat melakukan berbagai tindakan seperti mengadakan training dengan mengikuti perkembangan zaman melalui knowledge management yang baik dalam rangka upgrading skill dan kemampuan sumber daya manusia sebagai value creation demi meningkatnya performance karyawan untuk kemudian diharapkan dapat berdampak pada peningkatan nilai perusahaan, yang mana hal tersebut merupakan salah satu wujud dari tujuan perusahaan jangka panjang.

\section{DAFTAR PUSTAKA}

Abdiani, D. dan Nugrahanti, Y.W. 2014. Perbedaan Pengungkapan Intellectual Capital Berdasarkan Tipe Industri Dan Perbedaan Kapitalisasi Pasar Berdasarkan Pengungkapan Intellectual Capital. Jurnal CakrawalaAkuntansi.110-125.

Afabdi, D. dan Makaluas, J.L. 2016. Analisis Pelaporan Dan Pengungkapan Aset Tetap Di PT. Kemilau Nur Sian, Manado. Jurnal EMBA. 364-374. 
Gunawan, Barbara, Akhyar, Muhammad, \& Candrasari, Ratri. (1996). The Influence Of Intellectual Capital To The Company Value: The Financial Performance As Intervening Variable (Study At Lq45 Company In Idx In The Period OF 2011-2013). Universitas, 2016.

Dewi, A.A., Ayu, Kemara., dan Badjra, Ida Bagus., 2017. Pengaruh Profitabilitas, Akiva Tidak Berwujud, Ukuran Perusahaan, dan Struktur Modal Terhadap Nilai Perusahaan. EJournal Manajemen Unud. 21612190.

Dewi, N.A.C. dan Isynuwardhana, D. 2014. Pengaruh Keputusan Investasi, Keputusan Pendanaan Dan Kebijakan Dividen Terhadap Nilai Perusahaan Dengan Kinerja Keuangan Sebagai Variabel Intervening. Jurnal Perbankan dan Akuntansi. Vol 18 No 2.233-248.

Fahmi, Irham. 2014. Analisis Laporan Keuangan. Bandung: Alfabeta.

Faradina, dan Ike, G. 2016. Pengaruh Intellectual Capital Dan Intellectual Capital Disclosure Terhadap Kinerja Keuangan Perusahaan. EJurnal Akuntansi Universitas Udayana.1623-1653

Gultom, R., Agustina, Wijaya. 2013. Analisis Faktor-faktor yang Mempengaruhi Nilai Perusahaan pada Perusahaan Farmasi di Bursa Efek Indonesia. Jurnal Wira Ekonomi Mikroskil. Vol. 3 No. 1. 51-60.

Kurniawan, Robert. dan Yuniarto, Budi. 2016. Analisis Regresi: Dasar dan Penerapannya dengan $R$. Edisi 1,
Jakarta: Kencana.

Kusufiyah, Yunita Valentina, Dahar, Reni, \& Rahmi, Fitria. (2017). Efek Intellectual Capital terhadap Harga Saham dengan Kinerja Keuangan sebagai Variabel Moderating. Jurnal Ekonomi Dan Bisnis Dharma Andalas, 19(1), 150.

Liana, L. 2009. Penggunaan MRA dengan SPSS untuk Menguji Pengaruh Variabel Moderating terhadap Hubungan antara Variabel Independen dan Variabel Dependen.

Puspitasari, K. 2011. Implementasi Knowledge Management di PT Bank Mandiri. Bogor: Sekolah Pascasarjana Manajemen dan Bisnis IPB.

Priyono, 2016. Metode Penelitian Kuantitatif. Sidoarjo: Zifatama Publishing.

PSAK No. 19 tahun 2017 (revisi 2015) (IAI, 2017).

Rachmawati, R. 2015. Management Dynamical Conference. Pengungkapan Intellectual Capital. 1-19.

Rahmatullah, Indra. 2015. Aset Kekayaan Intelektual Sebagai Jaminan Dalam Perbankan. Edisi 1. Yogyakarta: Deepublish.

Sayyidah, U., Saifi, M. 2017. Jurnal Administrasi Bisnis. Pengaruh Intellectual Capital Terhadap Nilai Perusahaan dengan Profitabilitas sebagai Variabel Moderasi.

Siyoto, Sandu, \& Sodik, Muhammad Ali. (2015). Dasar metodologi penelitian. Literasi Media Publishing. 
Supriyono, R.A. 2018. Akuntansi Keperilakuan. Yogyakarta: Universitas Gadjah Mada.

Suroto. 2015. Jurnal Ilmiah UNTAG Semarang, Serat Acitya. Pengaruh Keputusan Investasi, Keputusan Pendanaan dan Kebijakan Dividen Terhadap Nilai Perusahaan.

Suyono. 2018. Analisis Regresi Untuk Penelitian. Edisi 1. Yogyakarta: Deepublish.

Solikhah, B., Abdul, R.H., dan Meiranto, W. 2010. Simposium Nasional Akuntansi XIII. Implikasi Intellectual Capital Terhadap Financial Performance, Growth Dan Market Value; Studi Empiris Dengan Pendekatan Simplistic Specification.

Solimun. Fernandes, A.A.R. dan Nurjannah. 2017. Metode Statistika Multivariat Pemodelan Persamaan Struktural (SEM) Pendekataan WarpPLS. Edisi 1. Malang: UB Press.

Ulum, I. $2015 . \quad$ Intellectual Capital: Model Pengukuran, Framework, dan Kinerja Organisasi. Edisi 1. Malang: Universitas Muhammadiyah Malang.

Wahyuni, S., Pujiharto. 2014. Mengukur Kinerja Intellectual Capital dengan Model VAIC.

Widoatmodjo, S. 2009. Pengantar dan
Studi Kasus Pasar Modal Indonesia. Ghalia Indonesia.

Wijayanti, P. 2012. Jurnal Ilmiah Fakultas Ekonomi dan Bisnis. Pengaruh Intellectual Capital Terhadap Harga Saham Melalui Kinerja Keuangan Pada Perusahaan Perbankan Yang Terdaftardi Bursa Efek Indonesia (BEI) Pada Tahun 2009 - 2011. hlm. 1-27.

Yuskar, Novita, D. 2014. Jurnal Manajeman dan Bisnis Sriwijaya. Analisis Pengaruh Intellectual Capital terhadapa Nilai Perusahaan dengan Kinerja Keuangan sebagai Variabel Intervening pada Perusahaan Perbankan di Indonesia.

Zamzami, Faiz. Dan Nusa, N.D. 2016. Akuntansi Pengantar 1. Edisi 1. Yogyakarta: Gadjah Mada University Press Anggota IKAPI.

Zulyati; dan Arya, N. 2011. Dinamika Keuangan dan Perbankan. Intellectual Capital dan Kinerja Keuangan Perusahaan. www.idx.com 